\title{
Application of Unmanned Aerial Vehicle Imagery for Algal Bloom Monitoring in River Basin
}

\author{
Heung-Min Kim ${ }^{1}$, Hong-Joo Yoon ${ }^{1}$, Seon Woong Jang ${ }^{2}$ Seok Nam Kwak ${ }^{3}$, \\ Byeong Yong Sohn ${ }^{4}$, Se Geun Kim ${ }^{4}$ and Dae Hyun Kim ${ }^{5 *}$ \\ ${ }^{1}$ Major in the division of Earth's Environmental System Science of Spatial \\ Information Engineering, Pukyong National University, (48513) 45, Yongso-ro, \\ Nam-Gu, Busan, South Korea \\ ${ }^{2}$ LIONPLUS CO., (47728) 38, Jungangdae-ro, Dongnae-Gu, Busan, South Korea \\ ${ }^{3}$ Environ-Ecological Engineering Institute CO., (48280) 9-32, 370 \\ Gwanganhaebyeon-ro, Suyeong-Gu, Busan, South Korea \\ ${ }^{4}$ Department of Dam \& Watershed, Korea Water Resources Corporation, \\ (34350), 200 Sintanjin-ro, Daedeok-Gu, Daejeon, South Korea \\ ${ }^{5}$ OCEANTECH CO., (10440) 262-29, Hangjuoe-Dong, Deokyang-Gu, Goyang-Si, \\ Gyeonggi-Do, South Korea \\ ${ }^{5}$ daehyun@gmail.com*
}

\begin{abstract}
The purpose of this study is to enhance control capability of river water quality and environment by developing algal bloom monitoring technology using Unmanned Aerial Vehicle. The study acquired remote sensing data using UAV on the midstream area of Nakdong River, one of four major rivers in South Korea. The study also conducted water quality analysis and spectral reflectance measuring in the field to identify emergence aspect of phytoplankton in waters of the river and to induce algal bloom detection index equation through wavelength mixing of sensors. The result showed that the result values of algal bloom detection obtained from wavelength band mixing had strong positive correlation with algae standing crops. Besides, the results of analyzing spatial distribution of algal bloom of the overall investigated water area showed that the area of $0.22 \mathrm{~km}^{2} \sim 0.26 \mathrm{~km}^{2}$ had severity equivalent to the level of warning $(5,000 \sim 1,000,000$ cells $(\mathrm{mL})$ in 2015 criteria for issuing algae warnings. It is expected that when this remote water quality and pollution monitoring technology is applied in the field, it would be able to improve capabilities to deal with the river water quality and pollution at the early stage.
\end{abstract}

Keywords: Algal Bloom, Unmanned Aerial Vehicle, Monitoring, Water Quality Exam, Spectral Reflectance

\section{Introduction}

Algal bloom refers to the phenomenon in lakes or river with slow flow velocity where the color of water changes into green due to rapid increase of algae such as Cyanobacteria, Chlorophyceae and Bacillariophyceae, which is caused by eutrophication [1]. Algal bloom has continuously been occurring from the past to the present, but with the rise of water temperature and pollution in the water environment, the frequency and severity is increasing even more [2-6]. Such massive reproduction of algae causes negative effects on use of water resources, including unpleasant taste and smell, impure water, and death of fish due to lack of oxygen in the water [7]. In Korea, water pollution caused by algal bloom has currently been bringing serious anxiety of people over safety of water supply sources and it is now being recognized as a national issue [8-10]. In the 
Korean Peninsula, four main rivers of Han River, Geum River, Nakdong River and Youngsan River are flowing across the country, and particularly in the case of Han River and Nakdong River, major big cities have been developed along the rivers which have been major sources of water supply for agricultural, industrial and drinking uses [11]. However, with worsening of eutrophication, continuous heat and drought, algal bloom in the water has increased, and it raised continuous water quality issues [12]. Therefore, in order to address the anxiety of people over use of drinking water and to supply stable water resources by securing clean water sources, it is urgently needed to develop technologies preventing water pollution caused by algal bloom. Furthermore, it is important to enhance capabilities to deal with emergence and distribution of algal bloom preemptively through regular forecasting and effective monitoring activities.

Currently, monitoring of algal bloom in Korea is conducted through local sampling in field investigations and aerial forecasting using manned vehicles. First, the sampling investigation is effective in identifying severity and conditions of algal bloom. However it costs a lot of time and research personnel, and it is not possible to identify spatial distribution such as the volume of emergence and expansion due to the characteristics of local investments [13]. Next, in the case of aerial forecasting using the manned vehicle, it is effective in identifying spatial distribution of algal bloom as it can monitor the whole range of the river within a short time. However, it costs enormous amount to operate the system regularly. When massive algal bloom occurs, aerial forecasting can provide information about the spatial expansion in the wide range, but when it comes to small and medium range of algal bloom around a river, interpretation can be difficult. Therefore, in order to enhance the capability to deal with emergence of algal bloom preemptively, it is required to develop a new kind of forecasting and monitoring system which can overcome limitations of the existing methods. This study attempts to develop algal bloom monitoring technology using unmanned aerial vehicle (UAV) which can implement effective interpretation of spatial distribution at a relatively lower cost compared to aerial forecasting and can overcome visual and spatial limitations of sampling investigation in order to improve controlling capability of river water quality and environment.

\section{Study Site}

Nakdong River locates at the southern east part of the Korean Peninsula and is the second largest river in Korea with length of $521.5 \mathrm{~km}$ and size of $23,717 \mathrm{~km}^{2}$ (Figure 1a) [14]. Total quantity of Nakdong River is 385 tons per year, and 9.5 billion tons (24.7\%) of water for use (industrial, agricultural, living and drinking purposes) are supplied to big cities converged with major industries and population such as Busan and Daegu Metropolitan Cities [15]. In the midstream and downstream where these big cities locate, water pollution is frequently occurring due to increased inflow of sewage and aggravation of eutrophication [12]. The present study targeted the midstream area of Nakdong River, in which all the administrative districts of Daegu Metropolitan City are located with high dependency of water resource uses and with frequent occurrence of algae related water pollution (Figure 1b). Among the midstream areas of Nakdong River, the selected site for the study is Dodong-ri, Guji-Myeon, Dalseong-gun, Daegu (Figure 1c), which was covered by Korean media several times due to the frequent occurrence and severity of algal bloom[19]. 


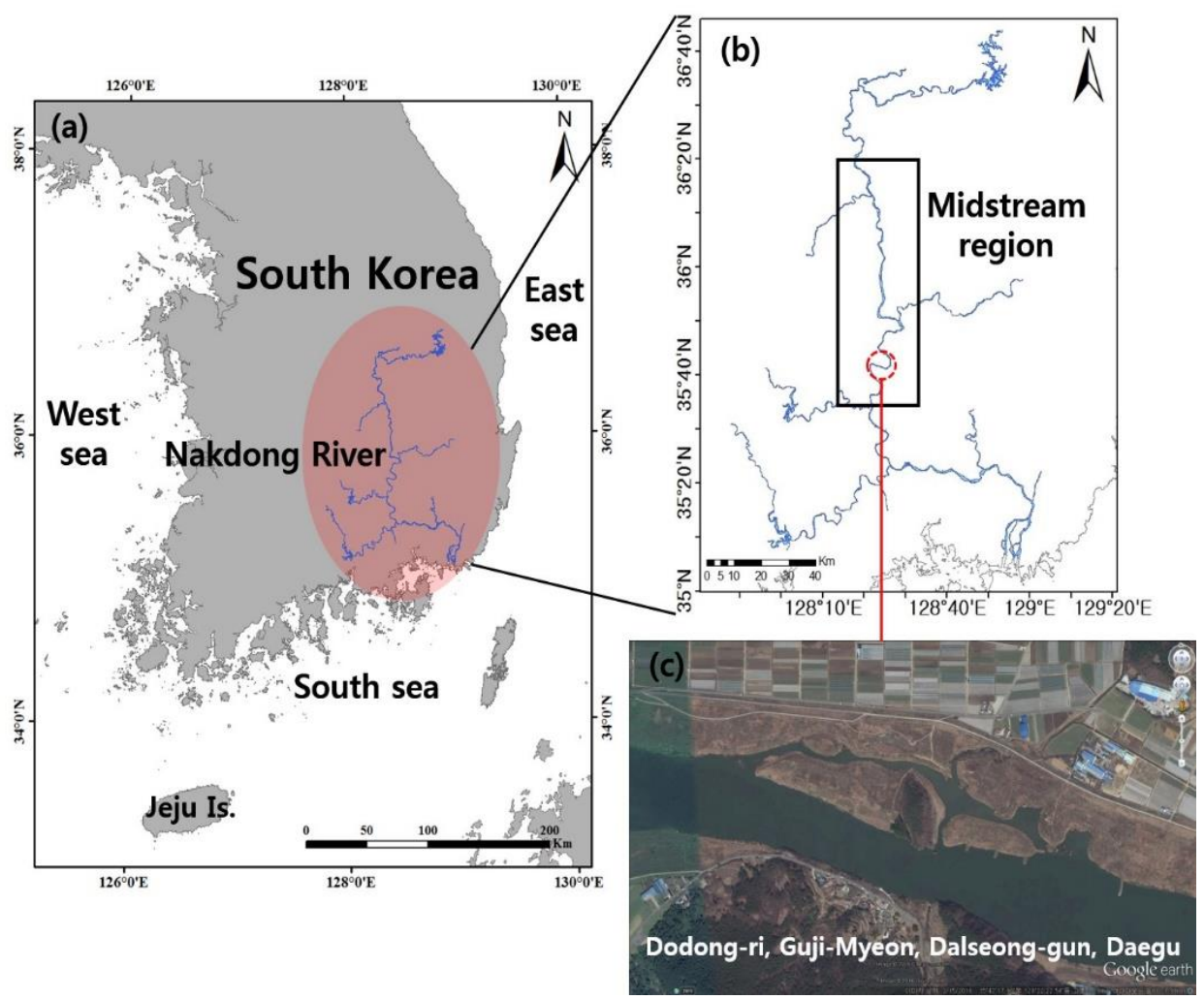

Figure 1. Location of the Nakdong River and Survey Area

\section{Methodology}

\subsection{UAV Imagery}

The existing remote sensing method using a satellite or manned vehicle is effective to observe a wide space in a short period. But, the limitation is that it costs a very high price for the operation and that it is difficult to use regularly [17].

Recently, the remote sensing method using unmanned aerial vehicle (UAV) is applied in various areas as an innovative multi-purpose tool to obtain data including geo-spatial information [13, 18-19]. Remote sensing method using UAV can implement operations regularly whenever necessary at a lower cost compared to manned vehicles or satellites to obtain spatio-temporal data in high resolution [20-23]. Besides, with its excellent mobility, it can be applied in places with difficult accessibility for human or in dangerous environments [24-26]. In this aspect, this UAV can be a new solution to supplement disadvantages of conventional remote sensing and field investigation methods.

UAV and Sensors Description. The unmanned aerial vehicle (UAV) used in this study is Sensefly Ltd's eBee (Figure 2a) which can make a long flight (single flight: 12 $\mathrm{km}^{2}$ at $974 \mathrm{~m}$ altitude) and can obtain high resolution images (ground sampling distance: down to $1.5 \mathrm{~cm}$ per pixel) [27]. 

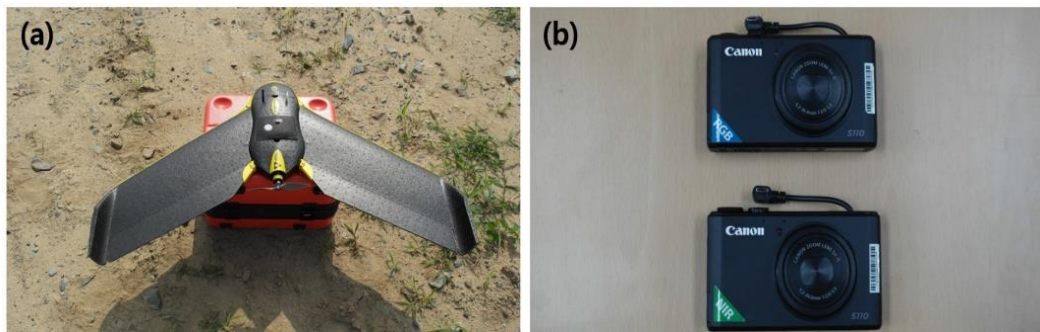

Figure 2. The Unmanned Aerial Vehicle and Sensor Used in this Study

eBee is a fixed wing UAV, with function of automatic flight using flight control software, GPS of the vehicle and IMU as well as the function of manual operation. The specification of eBee can be found in Table 1.

Table 1. Technical Specifications of the UAV Used in the Present Study [27]

\begin{tabular}{c|c}
\hline Weight & Approx. $0.69 \mathrm{~kg}$ \\
\hline wingspan & $96 \mathrm{~cm}$ \\
\hline Maximum flight time & $50 \mathrm{~min}$ \\
\hline Maximum coverage(single flight) & $12 \mathrm{~km}$ \\
\hline Nominal cruise speed & $40-90 \mathrm{~km} / \mathrm{h}$ \\
\hline Ground sampling distance & Down to $1.5 \mathrm{~cm}$ per pixel \\
\hline
\end{tabular}

Next, for the sensors to install in UAV for obtaining image materials, Canon Powershot S110 RGB and NIR were selected. Technical features of S110 RGB and NIR sensors are: Resolution -12 million pixels, Size $-7.44 \times 5.58 \mathrm{~mm}$, Weight $-0.7 \mathrm{~kg}$, Pixel pitch -1.86 um, Image format - JPEG and RAW (Figure 2b). S110 RGB sensor basically has the function of digital camera and provides standard band data of Red, Green and Blue to enable visible spectrum analysis of images. S110 NIR sensor consists of NIR (850 nm) band used to calculate NDVI (normalized difference vegetation index) for assessing biomass and plant health, apart from Green and Red band. The specific wavelength band of S110 RGB and NIR sensors are shown in Figure 3.

(a)

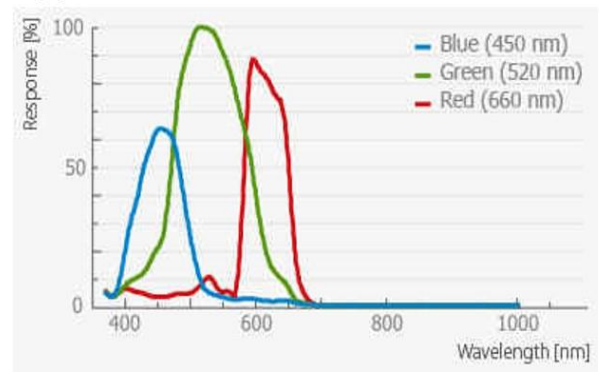

(b)

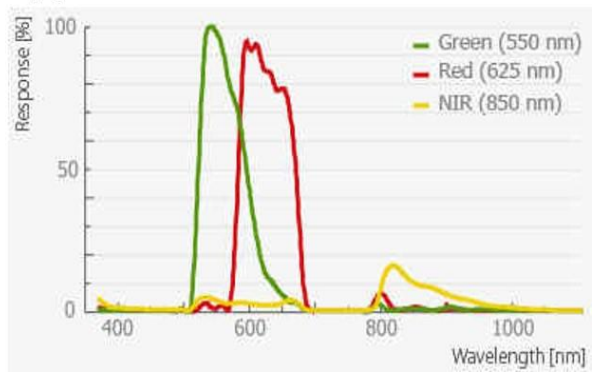

Figure 3. Spectral Performance of the Camera Sensors Mounted on the UAV: (a) RGB and (b) NIR sensors

UAV Image Acquisition nd Processing. Adequate flight planning for UAV is a very important part to acquire high quality data to meet the purpose of using the vehicle [23]. In this study to monitor algal bloom in the river, mission parameters for the photographic flight of UAV were established as follows: flight height $-400 \mathrm{~m}$ (ground resolution: 14 $\mathrm{cm} / \mathrm{pixel}$ ), single flight time - within 20 minutes, Flight strip - rectangular route (11 line) (Figure 4a). To generate orthomosaic images of the photographed area, the camera was 
set as follows: pixel size $-1.86 \mu \mathrm{m}$, focal length $-4.4 \mathrm{~mm}$, lateral overlap $-75 \%$, longitudinal $-70 \%$.

The actual monitoring of Nakdong River water area of Dodong-ri, Guji-Myeon, Dalseong-gun, Daegu (Figure 1c) was conducted two times on July $29^{\text {th }}$ and August $18^{\text {th }}$ 2015 when high severity of algal bloom continued since the first observation on June $10^{\text {th }}$ 2015 by the media [28]. As eBee is made of EPP foam material and has a light weight of $0.69 \mathrm{~kg}$, it is not possible to mount 2 sensors at the same time for a long flight. For this reason, the researcher mounted S110 RGB and NIR separately for each time of monitoring to acquire image data. In order to conduct monitoring of the river's reservoir area including the surrounding areas in a single flight, 57 photographing stations were required, and individual images with 4,000 (width) $\times 3,000$ (height) pixels were acquired (Figure 4b).

(a)

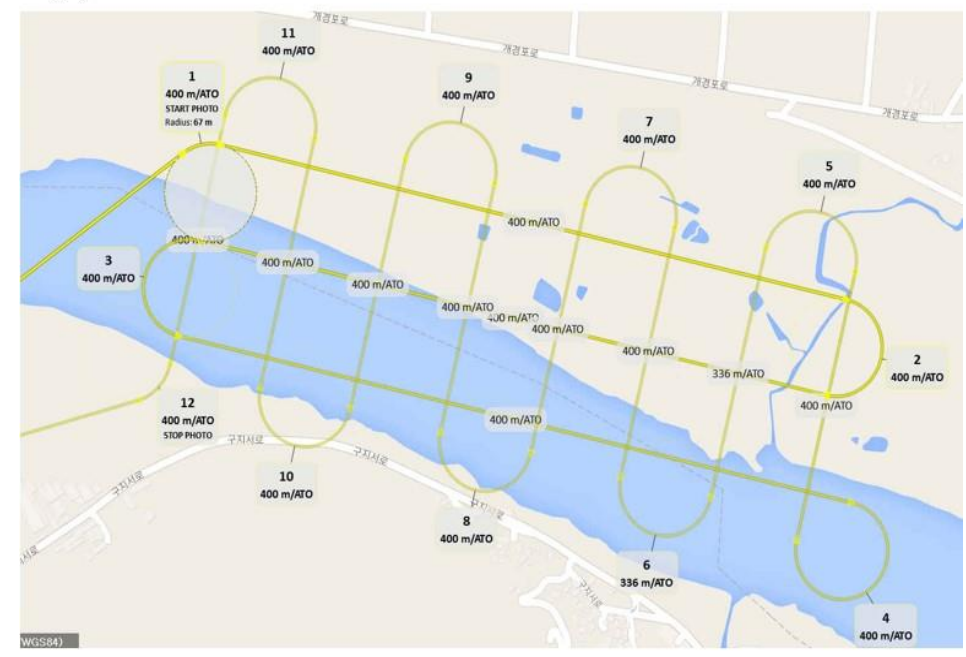

(b)

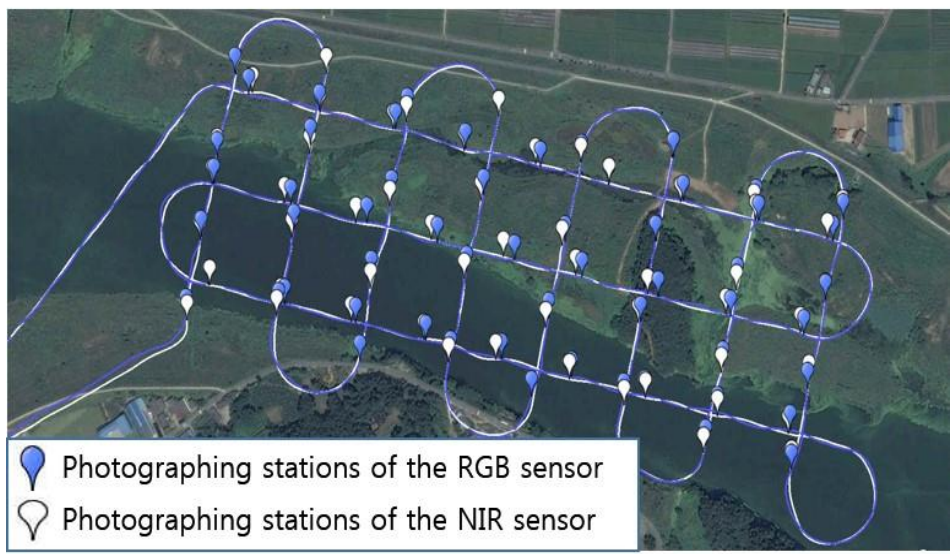

Figure 4. Flight Plan for Aerial Photography and Photographing Stations: (A) UAV Imaging Was Started At Position 1 and Ended At Position 12 and (B) Photographing Stations of Sensors

Individual images acquired through S110 RGB and NIR were implemented processes of geotagging and georeferencing through flight logs (latitude, longitude, altitude, accuracy horz $(\mathrm{m})$, accuracy vert $(\mathrm{m})$, etc.), which were recorded automatically by GPS and IMU sensors. Besides, in order to identify spatial distribution of algal bloom within the photographed reservoir area of the river, the researcher produced an orthomosaic 
image by matching georeferenced images (Figure 5). The information of orthomosaic images photographed on July $29^{\text {th }}$ and August $18^{\text {th }} 2015$ are shown in Table 2.
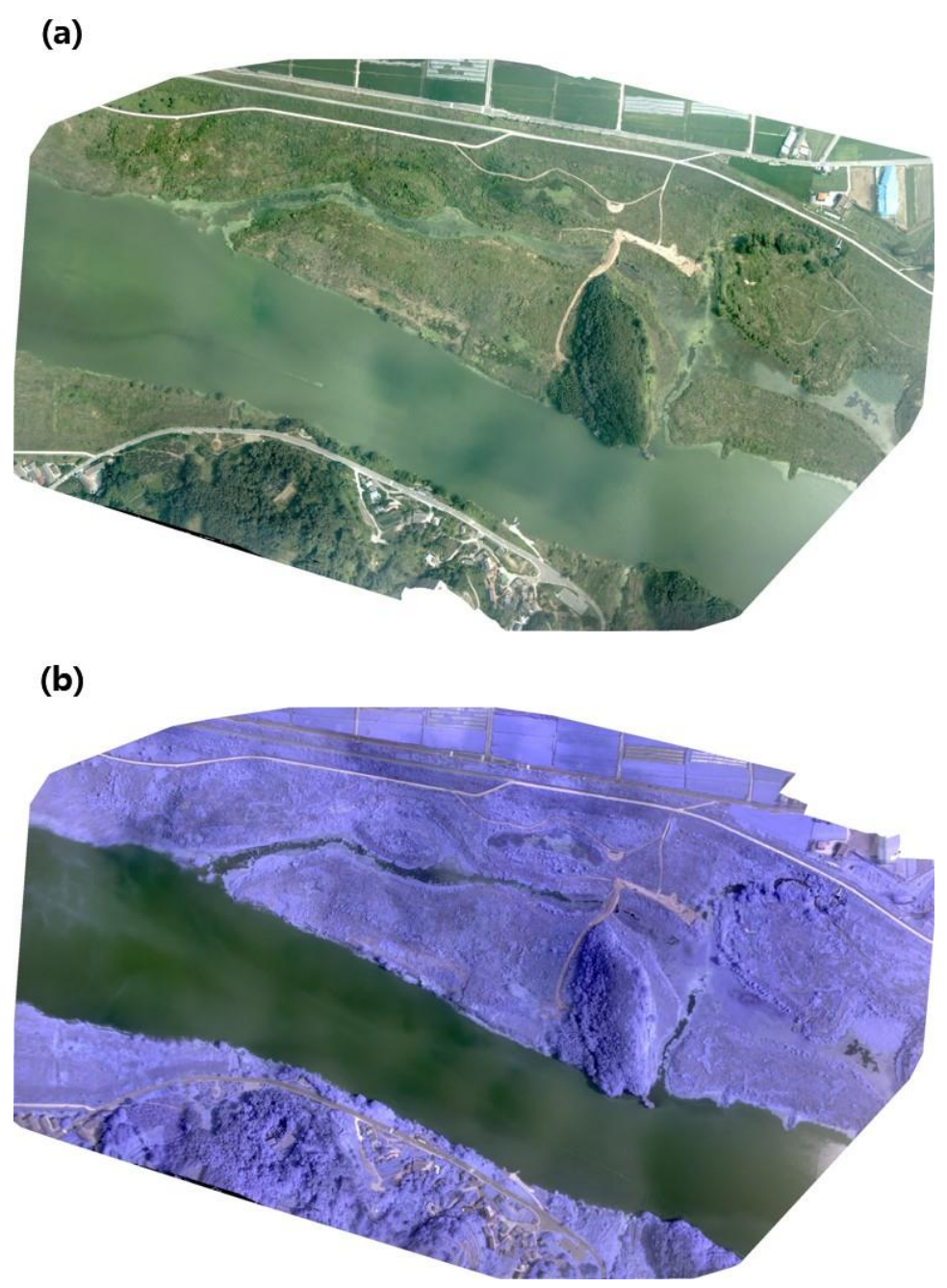

Figure 5. (a) RGB and (b) NIR Ortho Image Production through Image Preprocessing

Table 2. Results of Ortho Images Generation

\begin{tabular}{c|c|c}
\hline & $\mathbf{2 0 1 5 . 0 7 . 2 9}$ & $\mathbf{2 0 1 5 . 0 8 . 1 8}$ \\
\hline $\begin{array}{c}\text { Average ground sampling } \\
\text { distance(GSD) }\end{array}$ & $12.98 \mathrm{~cm} / 5.11 \mathrm{in}$ & $12.9 \mathrm{~cm} / 5.08 \mathrm{in}$ \\
\hline Area covered & $0.6291 \mathrm{~km}^{2} / 62.9085 \mathrm{ha}$ & $0.5847 \mathrm{~km}^{2} / 58.4716 \mathrm{ha}$ \\
\hline Image coordinate system & WGS 84 & WGS 84 \\
\hline Output coordinate system & WGS 84/UTM 52N & WGS 84/UTM 52N \\
\hline
\end{tabular}




\subsection{Water Quality Exam}

To identify emergence aspects of phytoplankton in the reservoir area of the river photographed by UAV and to examine the results of image detection by integrating the sensors' wavelength band mixing, the researcher conducted field investigation and quantity analysis of 18 sites on July $29^{\text {th }} 2015$ (Figure 6).

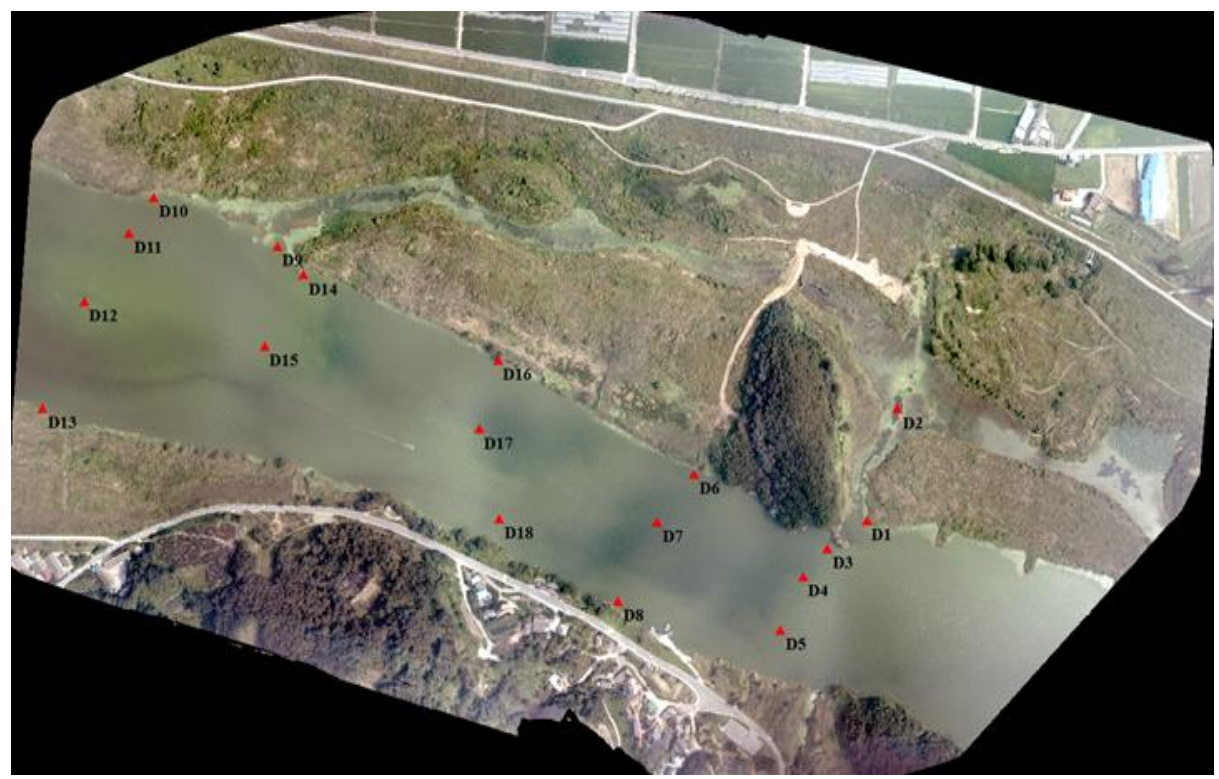

\section{Figure 6. The distribution of Sampling Sites for Water Quality Analysis in Unmanned Aerial Photograph Shooting Range}

For collection of water, the researcher made judgments about visually polluted sites and relatively unpolluted sites and filled in $1,000 \mathrm{~mL}$ bottles at each site while moving the sites by boat. At the same time, by using GPS, the researcher acquired location information of each site. The samples of collected water bottles were fixed with Lugol's solution at the site, and in order to prevent photo-oxidation, aluminum foils were wrapped around the bottle to shut off from the lights (Figure 7). Then, after precipitating the water in centrifuge tube for 48 hours, the researcher removed the supernatant and concentrated the water to $10 \mathrm{~mL}$ liquid. Sedgwick-Rafter Counting Chamber was used to yield the coefficient and it was indicated in the converted figures of emergence per unit volume (cells $/ \mathrm{mL}$ ). For species identification, the researcher used high magnification optical microscope (Motic BA210) to conduct analysis up to species level. In the case when the identification up to species level was difficult, the identification was conducted up to the upper level classification.

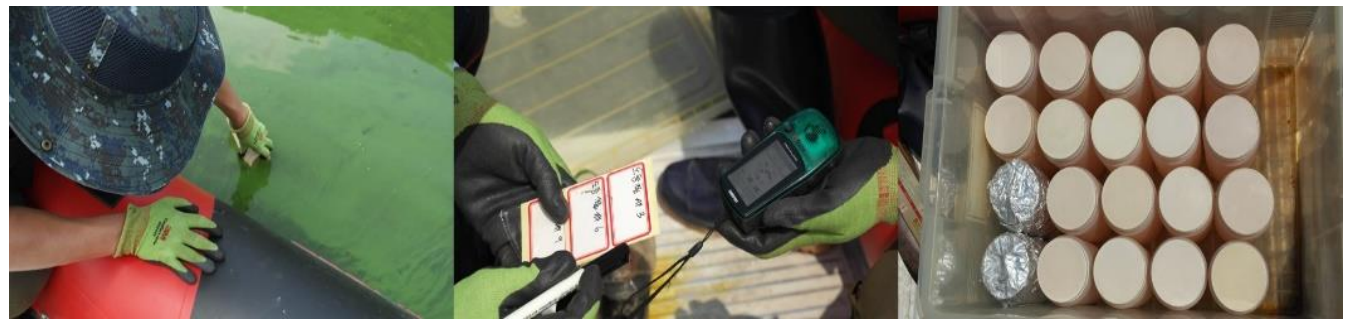

Figure 7. Field Water Sampling and Obtaining Coordinate Information at Each Points 


\subsection{Field Measurement of Spectral Reflectance}

The researcher conducted field spectral reflectance on reservoir area of the river using spectroradiometer to investigate algal bloom within the images generated from wavelength band mixing of UAV sensors. For measuring field spectral reflectance, the spectroradiometer was used with functions of wavelength range of $325 \mathrm{~nm}-1075 \mathrm{~nm}$, an accuracy of $\pm 1 \mathrm{~nm}$ and a resolution of $<3 \mathrm{~nm}$ at $700 \mathrm{~nm}$ (FieldSpec ${ }^{(5)}$ HandHeld2, ASD inc., USA). The researcher measured basic reflectivity using Spectralon panel $(10 \times 10-$ inch) with $99 \%$ reflectivity, and each reflectivity of totally 30 sites including 18 sites of water collection were measured (Figure 8). In order to minimize any noise from wind and so on at the point of measurement, the researcher measured 5 times at each site and used the mean value of the measured values.
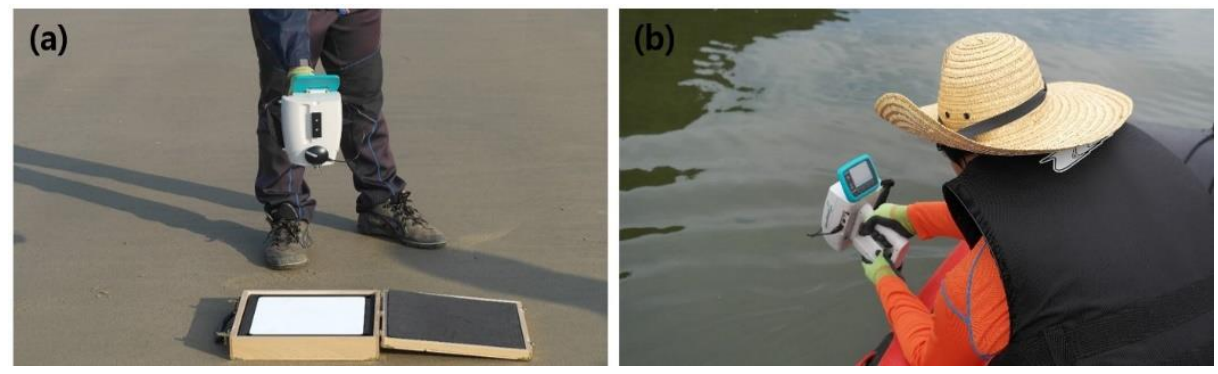

\section{Figure 8. Field Spectral Reflectance Measurement Using Spectroradiometer: (A) Reference Reflectance Measurement Using Spectralon Panel and (B) Water (Fresh and Algal Bloom) Reflectance Measurement}

\section{Results}

\subsection{The Emergence Aspects of Phytoplankton}

The species composition of phytoplankton emerged in the investigated water showed to be 16 species of 5 classification group. Among them, Cyanophyceae and Chlorophyceae accounted for the biggest proportion with 5 species $(31.3 \%)$ each, and followed by Bacillariophyceae, Euglenophyceae, and Dinophyceae, each of which with 1 species (Figure 9a). The result of analyzing the quantity of phytoplankton showed that the total standing crop was 9,639,001 cells/mL. Among this, Cyanophyceae accounted for $99.9 \%(9,637,026$ cells $/ \mathrm{mL})$ and the standing crops of other species were very low. When the standing crops of each collected site were compared, Site 10 showed the highest standing crop with 23,230 2,273,800 cells $/ \mathrm{mL}$ (mean value - 535,500 cells $/ \mathrm{mL}$ ) and Site 15 showed the lowest one (Figure 9b).

Cyanophyceae, which showed the highest standing crop, contains blue-green protein and cause algal bloom making the color of water dark green. Some of Cyanophyceae emit smelling material and small amount of toxin, which cause harm to the health. Ministry of Environment has designated and is managing 4 species of Cyanophycease including Microcystis sp., Anabaena sp., Oscillatoria sp., and Aphanizomenon as harmful cyanobacteria [29]. In the investigated area, among the 4 species of harmful cyanobacteria, Microcystis sp.(Figure 10a) and Anabaena sp.(Figure 10b) appeared as dominant species with 8,502,525 cells/mL (88.2\%) and $1,076,967$ cells $/ \mathrm{mL}(11.2 \%)$ respectively. The cell quantities of harmful cyanobacteria at each collected site are shown in Table 3. 
(a)

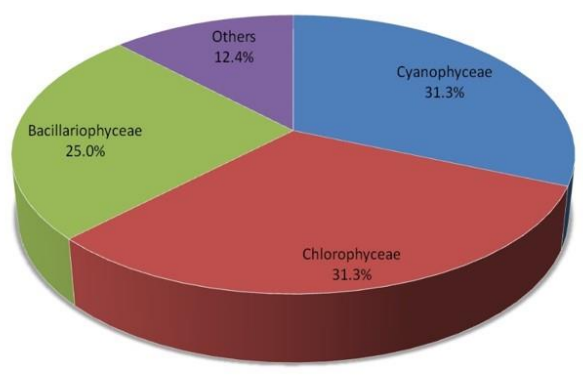

(b)

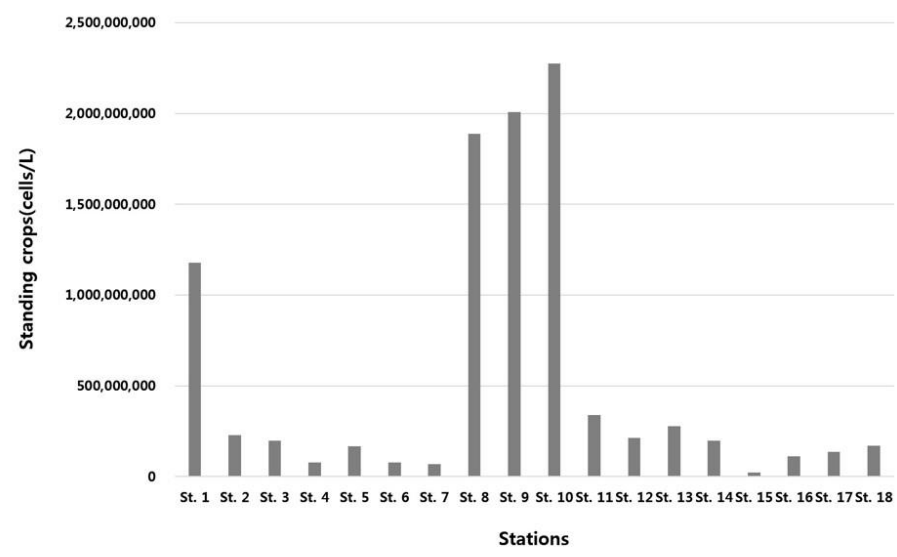

Figure 9. The Results of Water Quality Exam: (a) The Emergence Aspects of Phytoplankton and (B) Standing Crop of Phytoplankton at Each Sampling Sites
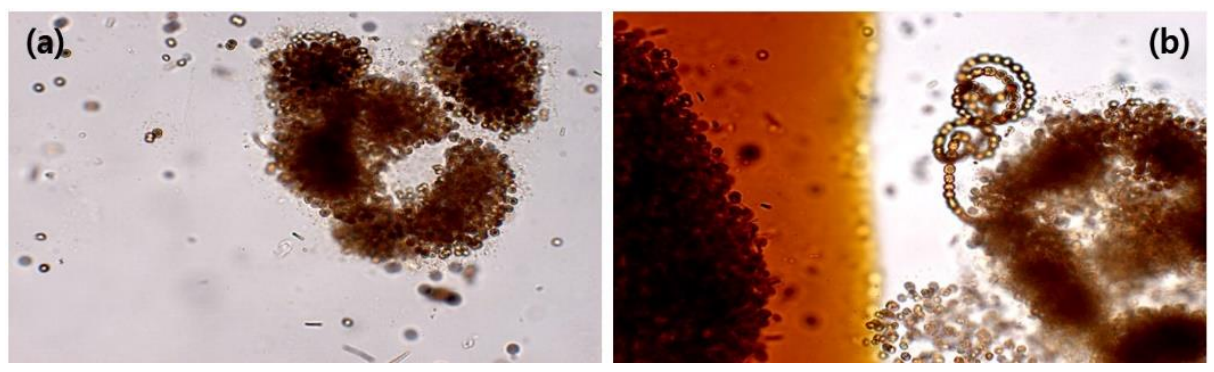

Figure 10. The Shape of Harmful Cyanobacteria Detected In the Study Area:

(A) Microcystis sp. and (B) Anabaena sp. 
Table 3. The Number of Harmful Cyanobacteria Cells Detected in Each Sampling Sites

\begin{tabular}{|c|c|c|c|c|c|}
\hline & & \multicolumn{3}{|c|}{ Harmful cyanobacteria } & \multirow{2}{*}{ Total } \\
\hline & & Microcystis sp. & Anabaena crassa & Anabaena sp. & \\
\hline \multirow{18}{*}{$\begin{array}{l}\text { Sampling } \\
\text { sites }\end{array}$} & St. 1 & $1,178,361$ & 0 & 0 & $1,178,361$ \\
\hline & St. 2 & 227,174 & 33 & 0 & 227,207 \\
\hline & St. 3 & 197,376 & 0 & 0 & 197,376 \\
\hline & St. 4 & 73,728 & 577 & 4,363 & 78,668 \\
\hline & St. 5 & 160,358 & 0 & 7,920 & 168,278 \\
\hline & St. 6 & 70,464 & 0 & 7,080 & 77,544 \\
\hline & St. 7 & 66,864 & 0 & 0 & 66,864 \\
\hline & St. 8 & $1,879,680$ & 0 & 8,400 & $1,888,080$ \\
\hline & St. 9 & $1,605,120$ & 0 & 401,280 & $2,006,400$ \\
\hline & St. 10 & $1,818,960$ & 0 & 454,740 & $2,273,700$ \\
\hline & St. 11 & 222,720 & 0 & 74,239 & 296,959 \\
\hline & St. 12 & 212,486 & 0 & 0 & 212,486 \\
\hline & St. 13 & 222,984 & 0 & 55,746 & 278,730 \\
\hline & St. 14 & 159,408 & 0 & 39852 & 199,260 \\
\hline & St. 15 & 20,582 & 0 & 2,572 & 23,154 \\
\hline & St. 16 & 94,147 & 0 & 15,691 & 109,838 \\
\hline & St. 17 & 126,547 & 0 & 1,204 & 127,751 \\
\hline & St. 18 & 165,564 & 0 & 3,878 & 169,442 \\
\hline \multicolumn{2}{|c|}{ Total } & $8,502,523$ & 610 & $1,076,965$ & $9,580,098$ \\
\hline
\end{tabular}

\subsection{Image Detection Results Using Algal Bloom Index}

The reflectivity of natural light reflected from the water surface changes depending on the condition of the surface. The investigated water areas can be broadly divided into conditions of relatively clear water and algal bloom emerged water, and there were differences in the reflectance depending on the condition of water surface in each site. As the quantity and quality of materials contained in the water surface can be different, the color or reflection of the water surface, i.e the signal strength of dispersed light is not same. Therefore, when it is measured by spectroradiometer, the resulting value can be different each time. This study attempted to develop algal bloom detection index equation by applying the method of algal bloom detection of water surface using artificial satellite [30]. Figure 11 
shows the graph of reflectance data measured in the conditions of relatively clear water surface and algal bloom emerged water surface.

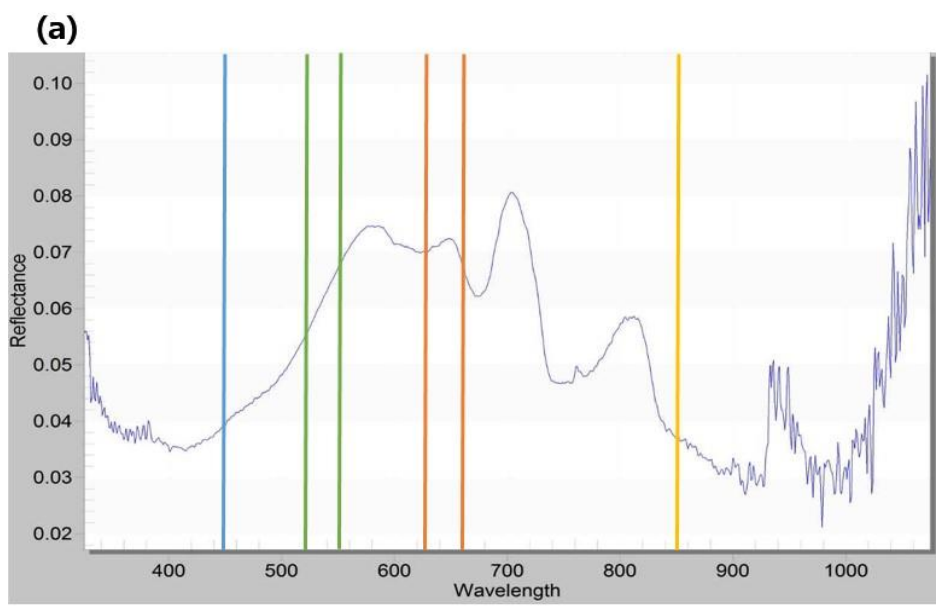

(b)

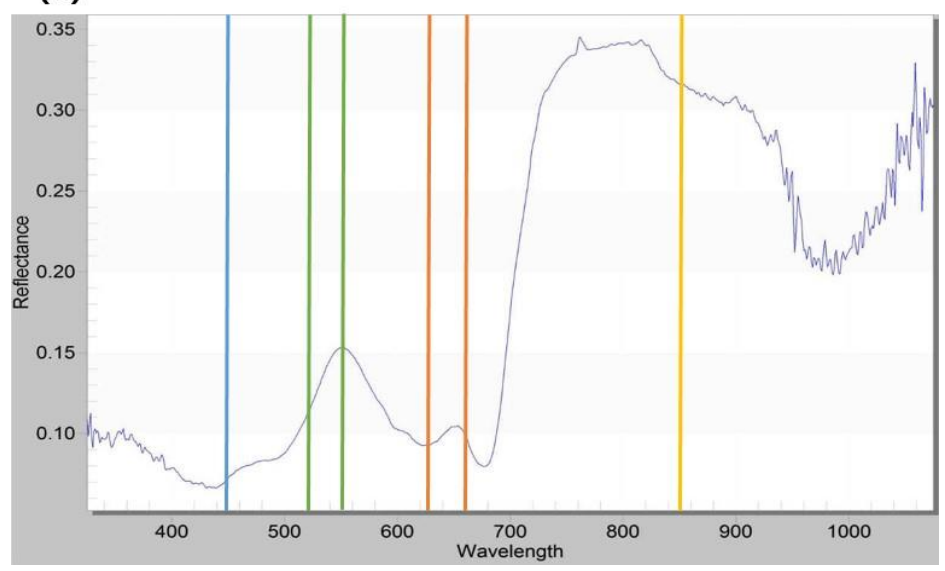

Figure 11. The Results of Field Spectral Reflectance Measurement Using Spectroradiometer: (A) Fresh Water and (B) Algal Bloom

When we examine the features of reflectance, the water surface in clear condition shows reflectance of 0.03 to maximum 0.1 in the range from Blue band to NIR band, and the reflectance by channels does not show significant difference (Figure 11a). However, in the case of algal bloom water, within the visible light, it showed the low peak in Red band and showed the reflectance not lower than 0.3 in NIR band (Figure 11b). Therefore, this study considered wavelength band of sensors mounted on UAV and drew Equation (1) by using the ratio of $660 \mathrm{~nm}$ showing the low peak reflectance and $850 \mathrm{~nm}$ showing the high peak.

$$
A I=\frac{R_{850 \mathrm{~nm}}-R_{660 \mathrm{~nm}}}{R_{850 \mathrm{~nm}}+R_{660 \mathrm{~nm}}}
$$

However, as the absolute value of the reflectance is not high, there's some limitation in the distinction between the conditions of clear water and algal bloom. Thus, by making the difference of the index values bigger, the study attempted to make this distinction more precisely and induced Detection Index (Equation (2)) by calculating Red band $(625 \mathrm{~nm})$ with bigger difference between the reflectance of clear water and algal bloom. 


$$
A I=\frac{R_{850 \mathrm{~nm}}-R_{660 \mathrm{~mm}}}{R_{850 \mathrm{~mm}}+R_{66 \mathrm{hm}}}+\frac{R_{850 \mathrm{~mm}}-R_{625 \mathrm{rm}}}{R_{850 \mathrm{~mm}}+R_{625 \mathrm{~mm}}}
$$

The results obtained by applying the induced Algal Bloom Detection Index are shown in Figure 12. The applied date was July $29^{\text {th }} 2015$ when unmanned aerial photographing, water collecting in the field and measuring of spectral reflectance were conducted at the same time. Except for the water surface, the land areas are inactivated, and the values of detected results are indicated in the form of index from 0 to 1 with no unit. The result of comparing Algal Bloom Detection Index and standing crops at each water collected site mentioned in 4.1 showed that the quantity of algae was smallest in D-15 with 23,230 cells $/ \mathrm{mL}$. The index value was 0.195 and indicated by red pixel. On the other hand, in D-10 with the largest quantity of algal emergence with $2,273,800$ cells $/ \mathrm{mL}$, the index value was 0.95 and indicated by green pixel. Based on this, the researcher compared correlation of the Index and algal stranding crops at 18 sites, and the result showed that the coefficient of determination $\left(\mathrm{R}^{2}\right)$ was 0.7206 having positive correlation (Figure 13). Therefore, it can be considered that the severity of algal bloom emergence is higher at green than red.

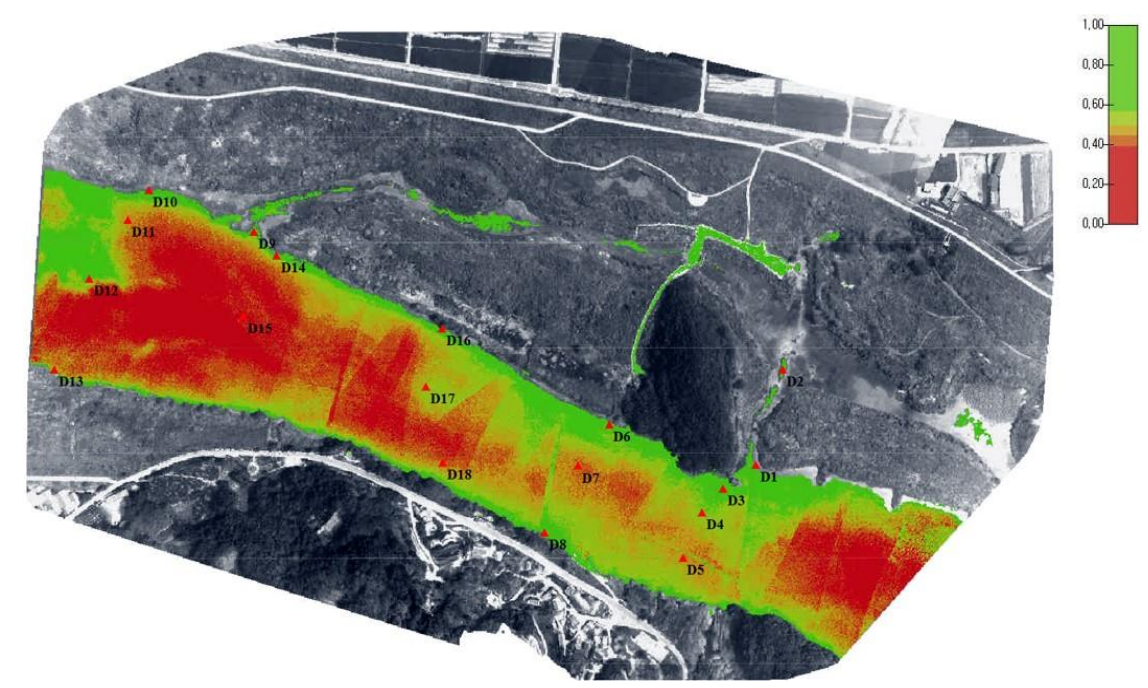

Figure 12. Detection Results through the Application of the Calculated Algal Bloom Index 




Figure 13. Correlation Analysis Result between Phytoplankton Concentration and Algal Bloom Index Value

\subsection{Estimating Spatial Distribution of Algal Bloom}

In Korea, algae warnings have been implemented since 1988 to secure safety of water supply source. Algae warnings are issued into Watch, Warning and Algal Bloom by classifying the degree of algal bloom emergence [29]. For the Algae Warnings Index, concentration of chlorophyll-a and quantity of harmful cyanobacteria cells are used. The criteria for issuing algae warnings in 2015, the year this study conducted, are shown in Table 4.

Table 2. Criteria and Indicators of Algae Bloom Warning System

\begin{tabular}{c|c|c}
\hline & Chlorophyll-a(mg/m $\left.\mathbf{m}^{\mathbf{3}}\right)$ & Cyanobacteria(cells/mL) \\
\hline Watch & 15 & 500 \\
\hline Warning & 25 & 5,000 \\
\hline Algal Bloom & 100 & $1,000,000$ \\
\hline
\end{tabular}

The study identified spatial distribution of algal bloom in the investigated area by applying the detection index to the above criteria for issuing algae warnings. In the case of July $29^{\text {th }} 2015$, the following data showed: Watch (not higher than 5,000 cells $/ \mathrm{mL})-0.06 \mathrm{~km}^{2}$, Warning $(5,000 \sim 1,000,000$ cells $/ \mathrm{mL})-0.22 \mathrm{~km}^{2}$, Algal Bloom (not lower than $1,000,000$ cells $/ \mathrm{mL}$ ) $-0.01 \mathrm{~km}^{2}$. The severity of emergence was the highest at both banks of the river (Figure 14a). On August $18^{\text {th }} 2015$, the area with concentration of algae equivalent to watch level was $0.02 \mathrm{~km}^{2}$. This indicates that $0.04 \mathrm{~km}^{2}$ decreased compared to that of July $29^{\text {th }} 2015$, however, the area with concentration of algae equivalent to Warning level increased to $0.26 \mathrm{~km}^{2}$ and the severity of algal bloom was more aggravated. Besides, the severity of emergence was highest in the left side water area within the image corresponding to the downstream of the river (Figure 14b). 


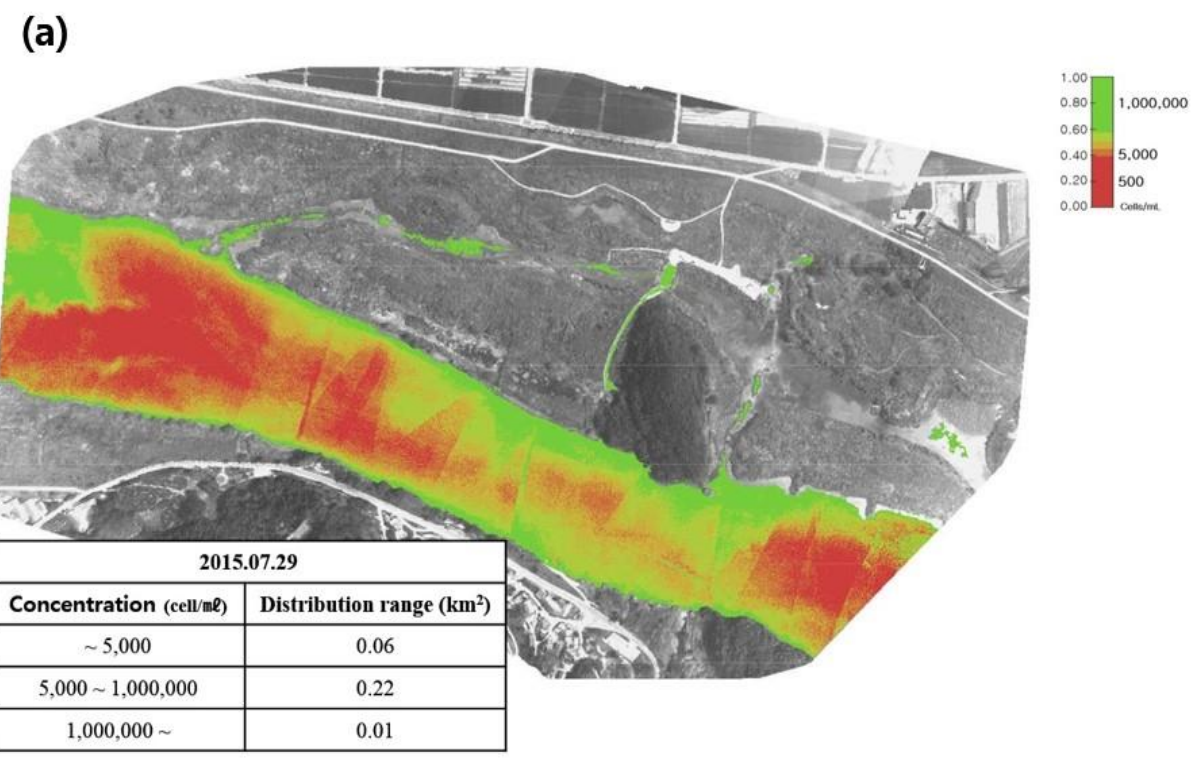

(b)

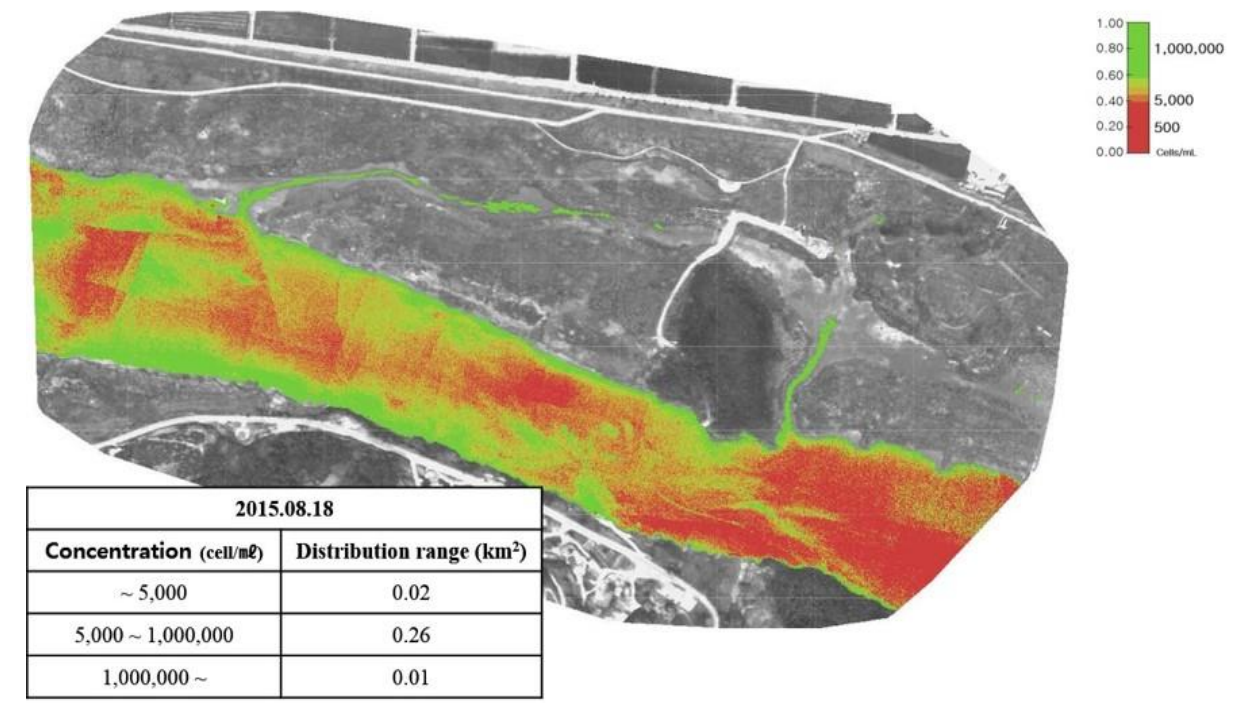

Figure 14. Spatial Distribution of Algal Bloom in the Survey Area Photographed by UAV: (a) 29 July 2015 and (b) 18 August 2015

\section{Discussion and Conclusion}

This study attempted to enhance controlling capability of river water quality and environment by developing algal bloom monitoring technology using UAV which can conduct effective interpretation of spatial distribution at a lower cost. For this purpose, the study obtained remote sensing data using UAV focusing on midstream areas of Nakdong River, with high dependency for water resource use and with frequent emergence of algae related water pollution. Besides, the study conducted spectral reflectance measuring of the sites and analysis of water quality to verify results and to induce algal bloom detection index equation through wavelength band mixing of sensors. The results showed that the algal bloom detection values obtained from wavelength band mixing of Red and NIR had highly positive correlation with algae standing crops at 18 sites. Besides, the result of analyzing spatial distribution of algal bloom on the overall investigated water area 
showed that the severity in the area from $0.22 \mathrm{~km}^{2}$ to $0.26 \mathrm{~km}^{2}$ was at the level of Warning $(5,000 \sim 1,000,000$ cells $/ \mathrm{mL})$ in the criteria for issuing algae warnings. This finding may suggest that the algal bloom monitoring technology using UAV presented in this study can be sufficiently utilized for controlling river water quality and environment. However, the study has limitations for verifying the accuracy because it did not consider monitoring of the river before algal bloom emergence and the results are obtained from only two occasions of monitoring. Therefore, in future, to apply the algal bloom remote monitoring technology using UAV in the actual field, it would be necessary to increase the reliability through additional water quality analysis on various water surface conditions depending on the degree of pollution along with continuous research on spectral features.

\section{Acknowledgments}

This paper is a revised and expanded version of a paper entitled "Algal Bloom Monitoring using UAVs Imagery" presented at 2016 The $5^{\text {th }}$ International Conference on Next Generation Computer and Information Technology at Harbin on August 19-20.

This research was a part of the project titled "The study on technology of detecting algal bloom and floating debris in the river using aerial images", funded by the Ministry of Land, Infrastructure and transport, Korea.

\section{References}

[1] S. H. Park, "Quantifying the algal blooms, the obliterated Nakdong River: A study of the controversy over the four major river project and the alger blooms (in Korea)", Seoul National University, Master's thesis, (2015).

[2] H. A. J. Senhorst and J. J. G. Zwolsman, "Climate change and effects on water quality: A first impression”, Water Science and Technology, vol. 51, no. 2, (2005), pp. 53-59.

[3] G. L. Boyer, "Monitoring harmful algal blooms in the Great lakes. Great Lakes Research Review", vol. 7, (2006), pp. 1.

[4] B. C. Bates, Z. W. Kundzewicz, S. Wu and J. P. Palutikof, (Eds.) "Climate change and water", Technical Paper, International panel on climate change (IPCC) Secretariat, Geneva, (2008).

[5] S. J. Thackeray, I. D. Jones and S. C. Maberly, "Long-term change in the phenology of spring phytoplankton: Species-specific responses to nutrient enrichment and climatic change", Journal of Ecology., vol. 96, no. 3, (2008), pp. 523-535.

[6] H. G. Park, "The occurrences and reduction measures of algal bloom (in Korea)", Bulletin of Korea Environmental Preservation Association., vol. 412, no. 7, (2014), pp. 17-21.

[7] M. W. Matthews, "Remote sensing of water quality parameters in Zeekoevlei, a hypertrophic, cyanobacteria-dominated late, Cape Town, South Africa", University of Cape Town, Master's thesis (2009).

[8] B. C. Kim, D. S. Kim and O. K. Kwon, "The trophic state of Lake Paldang (in Korean)", Journal of Korean Society on Water Environment., vol. 5, no. 2, (1989), pp. 39-46.

[9] H. W. Kim, K. Ha and G. J. Joo, "Eutrophication of the lower Nakdong River after the construction of an estuarine dam in 1987", International Review of Hydrobiology., vol. 83, (1998), pp. 65-72.

[10] H. W. Paerl and J. Huisman, "Blooms like it hot", Science., vol. 320, (2008), pp. 57-58.

[11] S. B. Park, "Algal blooms hit South Korean rivers", Nature news, (2012).

[12] A. Srivastava, C. Y. Ahn, R. K. Asthana, H. G. Lee and H. M. Oh, "Status, alert system, and prediction of cyanobacterial bloom in South Korea", Biomed Research International., vol. 2015, (2015), pp. 1-8.

[13] T. C. Su and H. T. Chou, "Application of multispectral sensors carried on unmanned aerial vehicle (UAV) to trophic state mapping of small reservoirs: A case study of Tain-Pu reservoir in Kinmen, Taiwan", Remote Sensing., vol. 7, no. 8, (2015), pp. 10078-10097.

[14] S. W. Jang, D. H. Kim, K. T. Seong, Y. H. Chung and H. J. Yoon, "Analysis of floating debris behavior in the Nakdong River basin of the southern Korean peninsula using satellite location tracking buoys", Marine Pollution Bulletin., vol. 88, (2014), pp. 275-283.

[15] Ministry of Environment- Nakdong River Basin Environmental Office, http://www.me.go.kr/ndg/.

[16] Y.News, "Algal bloom occur everywhere in the Nakdong River including Haman Barrage (in Korea)", June 16, (2015). 
[17] T. Hakala, J. Suomalainen and J. I. Peltoniemi, "Acquisition of bidirectional reflectance factor dataset using a micro unmanned aerial vehicle and a consumer camera”, Remote Sensing., vol. 2, no. 3, (2010), pp. 819-832.

[18] S. W. Jang, S. K. Lee, D. H. Kim, Y. H. Chung and H. J. Yoon, "Application of remote environmental monitoring technique to efficient management of beach litter", International Journal of $u$ - and e- Service, Science and Technology., vol. 8, no. 7, (2015), pp. 357-368.

[19] X. Tianyun, T. Xiaocheng, Y. Defang, X. Yonghe and Y. Hongliang, "UAV remote sensing applications in large-scale mapping in the hilly region of Tibetan Plateau", International Journal of Control and Automation., vol. 8, no. 3, (2015), pp. 279-286.

[20] A. S. Laliberte, A. Rango, J. E. Herrick, E. L. Fredrickson and L. Burkett, "An object-based image analysis approach for determining fractional cover of senescent and green vegetation with digital plot photography", Journal of Arid Environments., vol. 69, (2007), pp. 1-14.

[21] R. Dunford, K. Michel, M. Gagnage, H. Piègay and M. L. Trèmelo, "Potential and constraints of Unmanned Aerial Vehicle technology for the characterization of Mediterranean riparian forest", International Journal of Remote Sensing., vol. 30, (2009), pp. 4915-4935.

[22] J. Berni, P. J. Zarco-Tejada, L. Suarez and E. Fereres, "Thermal and narrowband multispectral remote sensing for vegetation monitoring from an unmanned aerial vehicle", IEEE Transactions on Geoscience and Remote Sensing., vol. 47, no. 3, (2009), pp. 722-738.

[23] S. Del Pozo, P. Rodríguez-Gonzálvez, D. Hernández-López and B. Felipe-García, "Vicarious radiometric calibration of a multispectral camera on board an Unmanned Aerial System", Remote Sensing., vol. 6, no. 3, (2014), pp. 1918-1937.

[24] H. S. Jang and T. H. Roh, "Extraction of horizontal alignment information using RC helicopter photogrammetric system (in Korean)", Journal of the Korea Association of Geographic Information Studies., vol. 8, no. 4, (2005), pp. 44-51.

[25] J. Everaerts, "The use of unmanned aerial vehicles (UAVs) for remote sensing and mapping. In proceeding of the International Archives of the Photogrammetry", Remote Sensing and Spatial Information Sciences, Beijing, China, (2008), July 5-7.

[26] S. W. Jang, S. K. Lee, S. Y. Oh, D. H. Kim and H. J. Yoon, "The application of unmanned aerial photography for effective monitoring of marine debris", Journal of the Korean Society of Marine Environment \& Safety., vol. 17, no. 4, (2011), pp. 307-314.

[27] Sensefly. https://www.sensefly.com.

[28] E-today News, "This year algal bloom occurred at the Dodong Pier in the Nakdong River (in Korea)", June 10, (2015)

[29] Ministry of Environment, "Systematic algal bloom management through the improvement of algae warnings. Press release (in Korean)", (2015).

[30] Y. M. Kim, Y. G. Byun, Y. Huh and K.Y. Yu, "Detection of cochlodinium polykrikoides red tide using MODIS level 2 data in coastal waters (in Korean)", Journal of The Korean Society of Civil Engineers, vol. 27, (2007), pp. 535-540.

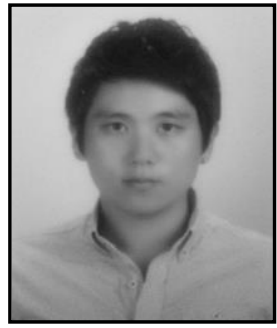

\section{Authors}

Heung Min Kim, he received the B.S. degree in Dept. of Spatial Information Engineering from Pukyong National University, Busan in 2015. He is a graduate school student in Dept. of Spatial Information Engineering of Pukyong National University.

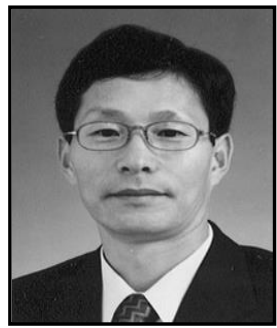

Hong Joo Yoon, he is professor and his academic degrees are Master in Ocean Dynamics (Pukyong National University, Korea), DEA in Atmospheric Dynamics (Paris VI University, France) and Doctor in Geodynamics (Grenoble I University, France). His special fields are Satellite Remote Sensing (Satellite Oceanography and Meteorology) and Marine \& Fisheries GIS. His recently studying the main subjects are change of climate, variations of SSH\&SST, ocean circulation and application of Big data in ocean. 


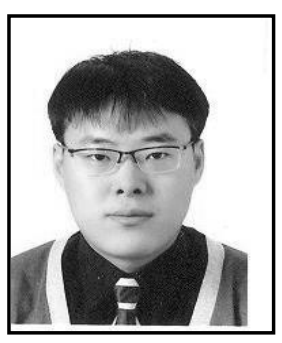

Seon Woong Jang, he is a research scientist at the LIONPLUS Co, Ltd.. He received the M.S., and Ph.D. degrees in Dept. of Spatial Information Engineering from Pukyong National University in 2012, and 2015 respectively. His research interests include remote sensing, environmental monitoring.

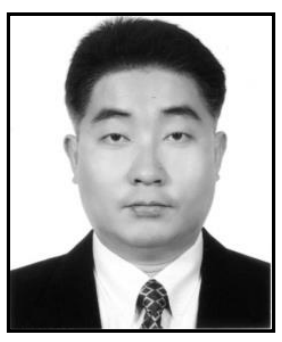

Seok Nam Kwak, he is a CEO at the Environ-Ecological Engineering Insititute Co, Ltd.. He received the M.S., and Ph.D. degree in Department of Oceanography from Pukyong National University in 1991, and 1997 respectively. His research interests include environmental ecology and biological oceanography.

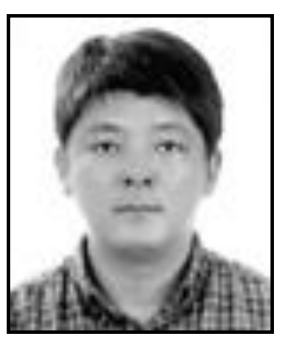

Dae Hyun Kim, he is a research scientist at the OCEANTECH Co, Ltd.. He received the M.S., and Ph.D. degrees in Department of Oceanography from Pukyong National University in 1998, and 2008 respectively. His research interests include remote sensing, coastal upwelling, HF radar and climate change. 
International Journal of Control and Automation Vol. 9, No. 12 (2016) 